\title{
Effect of Moringa leaf extract and set size on the bulb weight, diameter and yield of onions (Allium cepa $\mathrm{L}$.)
}

\author{
Arshad Yaseen ${ }^{1,2}$ - Maria Takacs-Hajos ${ }^{1}$ \\ ${ }^{1}$ University of Debrecen, Faculty of Agricultural and Food Sciences and Environmental Management, Institute of Horticultural Science, \\ H-4032 Debrecen, Böszörményi Street 138. \\ ${ }^{2}$ Salahaddin University-Erbil, College of Agricultural Engineering Sciences, Department of Horticulture, Kurdistan Region, Iraq \\ Kirkuk Road, 44002 \\ arshad.yaseen@agr.unideb.hu
}

\begin{abstract}
SUMMARY
Studying the use of natural extracts or biostimulants in improving vegetable plants is the current needs as an alternative way to the use of chemical products. This experiment was carried out to evaluate the effect of Moringa oleifera leaf extract (MLE) as a natural growth regulator on bulb diameter, weight and yield of onions 'Texas Early White' cultivar. Therefore, three concentrations (control, 2\%, 4\% and 6\%) of MLE and three different onion set sizes [small $(3 \pm 1 \mathrm{~g} /$ set $)$, medium $(6 \pm 1 \mathrm{~g} / \mathrm{set})$, and large $(10 \pm 1 \mathrm{~g} / \mathrm{set})]$ were prepared in a randomized complete block design with three replications and plant spacing $20 \times 15 \mathrm{~cm}$. MLE was applied as a foliar spray directly onto the plants with the amount of $25 \mathrm{ml}$ plant every two weeks from sprouting to maturity. The achieved results indicate that the interaction of foliar spray with moringa leaf extract $4 \%$ and large set size of $10 \pm 1 \mathrm{~g} /$ set gave the highest value of the total yield $4802.7 \mathrm{~g} \mathrm{~m}^{-2}$, while the lowest yield $1531 \mathrm{~g} \mathrm{~m}^{-2}$ was recorded in the interaction of control and the smallest set size of $3 \pm 1 \mathrm{~g} / \mathrm{set}$. Also, a significant difference was recorded in bulb diameter separately. Thus, the largest bulb diameter $68.90 \mathrm{~mm}$ was obtained from the planting of the largest set size $10 \pm 1 \mathrm{~g} / \mathrm{set}$ with $4 \%$ of MLE while the smallest bulb diameter $38.40 \mathrm{~mm}$ was recorded from the smallest set size $3 \pm 1 \mathrm{~g} / \mathrm{set}$ with control treatment. Similarly, a significant effect was recorded in both set size and MLE separately. The highest bulb diameter $58.71 \mathrm{~mm}$ was achieved in the planting of the largest sets $10 \pm 1 \mathrm{~g} /$ set, while the lowest diameter was $42.12 \mathrm{~mm}$ in the planting of the smallest set size $3 \pm 1 \mathrm{~g} /$ set. Similar results were recorded for the bulb weight and total yield. The concentration of $4 \%$ MLE produced the highest bulb weight $99.74 \mathrm{~g} / \mathrm{bulb}$ and yield $3324.5 \mathrm{~g} \mathrm{~m}^{-2}$, while the lowest bulb weight and yield was obtained in the control treatment $55.61 \mathrm{~g} / \mathrm{bulb}$, and $1869.3 \mathrm{~g} \mathrm{~m}^{-2}$. Consequently, the results indicate the positive effect of Moringa leaf extract which can be applied as a natural substance in the form of foliar spray at critical growth stages to improve the growth and yield of dry onions.
\end{abstract}

Keywords: Onions (Allium cepa L.), Moringa oleifera leaf extract (MLE), foliar spray, bulb diameter, bulb weight and total yield $\left(\mathrm{g} \mathrm{m}^{-2}\right)$

\section{INTRODUCTION}

Onion (Allium cepa L.) is a member of the Liliaceae family native in central Asia (Hanelt, 1990). This vegetable has been consumed for about 4000 years in middle Asia, Egypt, and the Mediterranean Region. Plants in this family are known as a cool-season biennial vegetable. They produce leaves and bulbs in the first year and flowers in the second year. Onions are accounted as one of the most important vegetables due to their nutritional value as vitamins (pro $\mathrm{A}, \mathrm{B}_{6}, \mathrm{~B}_{9}$, and $\mathrm{C}$ ), soluble sugars, minerals $\mathrm{Ca}, \mathrm{P}, \mathrm{Fe}, \mathrm{Cu}, \mathrm{K}, \mathrm{Zn}$ and $\mathrm{S}$ which has anti-microbial and anti-fungal effects and it makes to be highly precious healthy product to the human health (Griffiths et al., 2002). It is the major ingredient in different dishes traditional or fast foods like a salad or cooked. Onion production is increasing year by year, the leading onion producer countries are China, India, the USA and Turkey. In the last few decades, the world dry onion production has been increasing by $20 \%$, the latest data was about 97.8 million tons in 2017 (FAO, 2017). Researchers have found that improving yield has been limited to many factors such as environmental, technical, agronomic practices and cultivars (Hassan M. and Ayoub, 1978; Mondal et al., 1986; Ruiter, 1986; Yamaguchi et al., 1975). Essential nutrients are necessary for the plant yield, while growth regulators are essential for plant growth and development (Taiz and Zeiger, 2010).
Mvumi (2013) reported that plant hormones influence every phase of the plant growth and development so that it can be used to increase plant growth and development. In general, auxins, gibberellins, abscisic acid, ethylene and cytokinin are the most common growth hormones and synthetic substances. Each of these substances works on a specific part of plant cells as cytokinin regulates cell division and inspires leaf surface, involved in cell growth and differentiation, and their exogenous supply delays senescence of crop plants (Prosecus, 2006). The leaf of Moringa oleifera contains natural derivate of cytokinin, phenolics, ascorbates, vitamins, several mineral elements and essential amino acids (Antwi-Boasiako and Enninful, 2011; Fuglie, 2000, 2009; Rady and Mohamed, 2015). The leaf extract has been used as a natural plant growth regulator in different vegetables such as tomatoes (Culver et al., 2012), pepper (Matthew, 2016), lettuce (El-saady and Omar, 2017), and garlic (Hegazi et al., 2016). Mohammed et al. (2013) mentioned that natural zeatin, which is one of the active plant hormone substances in the cytokinin group, can be found in fresh Moringa leaf juice. Onion set size, on the other hand, is an effective factor which influences the yield and quality (Addai, 2014; Islam et al., 1999; Rabinowitch, 1979). Matimati (2006) indicated the variation of the differences between varieties in response to the bulb set size in onion marketable yield. There is still very limited information on the use of Moringa extract and 
the proper set size for planting onions to produce the optimum yield by many local growers. Therefore, the present study was carried out to investigate the effects of bulb size and Moringa leaf extract on the onion yield.

\section{MATERIALS AND METHODS}

\section{The experimental site, design and treatments}

This study was carried out in two factorial experimental designs, the first was the use of the different size of sets, the second, was different concentration of the Moringa leaf extract. Three different set sizes of 'Texas Early White' onion variety [small $(3 \pm 1 \mathrm{~g} / \mathrm{set})$, medium $(6 \pm 1 \mathrm{~g} / \mathrm{set})$, and large $(10 \pm 1$ $\mathrm{g} / \mathrm{set}$ )] was grown in a sandy loam soil with $\mathrm{pH} 7.5$. The row distance was $20 \mathrm{~cm}$ and $15 \mathrm{~cm}$ between the sets in the row. The plot size was $1 \mathrm{~m}^{2}$. The field experiment was carried out in a randomized complete block design with three replications. Moringa leaf extract (MLE) with concentrations of $2 \%, 4 \%$ and $6 \%$ was prepared. After the dilution of the MLE to the concentration requirements, the extract was directly sprayed onto the plant leaves for four times once per two weeks interval from the sprouting to the maturity, while the control plots spayed with distilled water only.

\section{Preparation of the Moringa leaf extract (MLE)}

The chemical composition of Moringa oleifera was published by Fuglie (1999) which is given in Table 1. The leaf extract was prepared according to Fuglie (2000). Fresh green leaves of Moringa tree (Figure 1) was collected, washed, cleaned and stored at $4{ }^{\circ} \mathrm{C}$ for 24 hours. After it the leaves was crushed using a blender to extract the juice then the juice filtered using Whatman filter paper No 2, as it is developed by Sreelatha and Padma (2009). Finally, the extracted juice was diluted to the concentration of $2 \%, 4 \%$ and $6 \%$ with Tween-20 additionally added in $0.01 \%$ as a surfactant. The diluted solution was directly sprayed onto the onion leaves with the amount of $25 \mathrm{ml} /$ plant.

Table 1

Chemical components of $100 \mathrm{~g}$ Moringa oleifera leaf powder

\begin{tabular}{|c|c|}
\hline Chemical components in $100 \mathrm{~g}$ dry weight & Amount \\
\hline Moisture (\%) & 7.50 \\
\hline Protein $(g)$ & 27.1 \\
\hline Fat $(\mathrm{g})$ & 2.30 \\
\hline Carbohydrate (g) & 38.2 \\
\hline Fiber $(\mathrm{g})$ & 19.2 \\
\hline Calcium (mg) & 2.00 \\
\hline Magnesium (mg) & 368 \\
\hline Phosphorus (mg) & 204 \\
\hline Potassium (mg) & 1.32 \\
\hline Copper (mg) & 0.60 \\
\hline Iron $(\mathrm{mg})$ & 28.2 \\
\hline Sulphur(mg) & 870 \\
\hline Vitamin $\mathrm{A}(\beta$-carotene $)(\mathrm{mg})$ & 16.3 \\
\hline Vitamin $\mathrm{B}_{1}$ (thiamine) (mg) & 2.60 \\
\hline Vitamin $B_{2}$ (riboflavin) (mg) & 20.5 \\
\hline Vitamin $B_{3}$ (nicotinic acid) (mg) & 8.20 \\
\hline Vitamin C (ascorbic acid) (mg) & 17.3 \\
\hline Vitamin E (tocopherol acetate) (mg) & 113 \\
\hline
\end{tabular}

Source: Fuglie (1999)

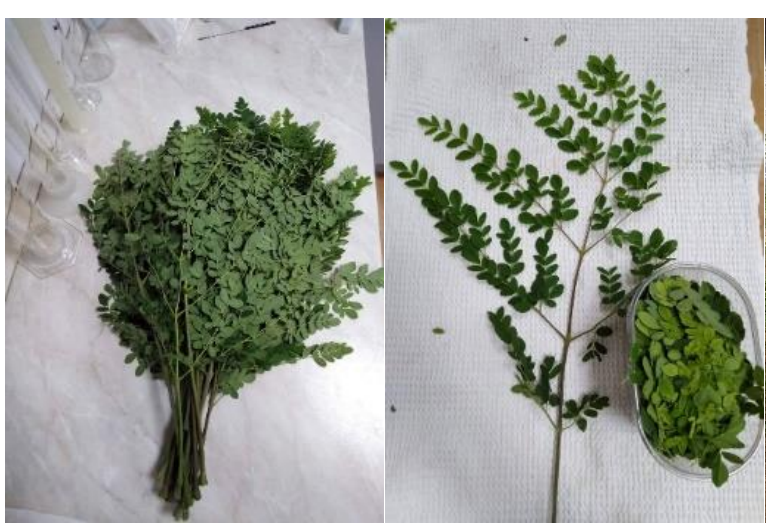

\section{Measurements and data collection}

The harvest time started while the maturity was in the optimal stage. The physiological maturity of onions is when $80 \%$ of leaves turning to yellow (Abdissa et al., 2011). To measure the samples, four samples in each replication was randomly selected. The selected plants were used for each growth measuring parameters and their averages was taken for the statistical analysis. After harvest, the following parameters was measured; bulb diameter (mm) measurement with Digital Vernier calliper, Weight of bulbs (g) - using a Mettler Balance

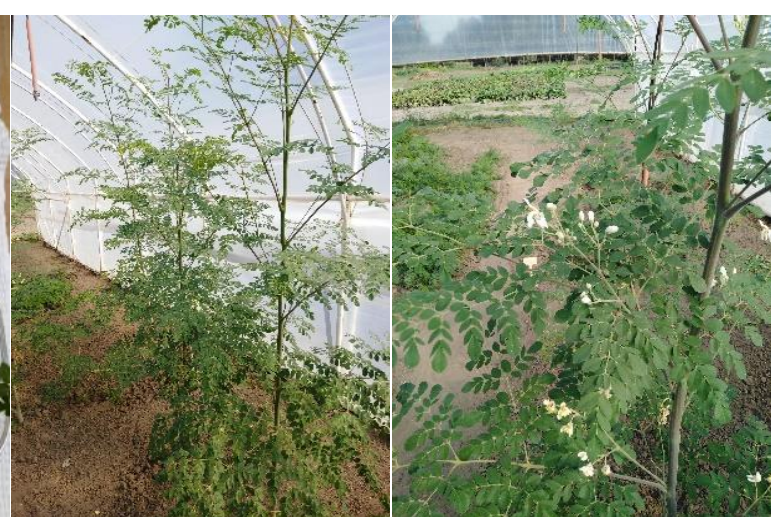

Model PN 163 and total yield of bulb weight $\left(\mathrm{g} \mathrm{m}^{-2}\right)$. Collected data were analysed using Analysis of Variance and the mean differences according to Duncan's Multiple Range at $\mathrm{p} \leq 0.05$.

\section{RESULTS AND DISCUSSION}

Effect of set size on bulb diameter, weight and total yield $\left(\mathrm{g} \mathrm{m}^{-2}\right)$ of onion

Set size significantly influenced the bulb diameter, weight and yield. Bigger set size recorded the higher 
result in all of the parameters (Table 2). However, nonsignificant different was recorded between the medium and large set size of $10 \pm 1 \mathrm{~g} / \mathrm{set}$ and $6 \pm 1 \mathrm{~g} / \mathrm{set}$, mean diameters of the bulb were $58.71 \mathrm{~mm}$ and $55.53 \mathrm{~mm}$ respectively.

Table 2

Effect of Set size on bulb diameter, weight, and total yield ( $\mathrm{g} \mathrm{m}$ $\left.{ }^{2}\right)$ of onion

\begin{tabular}{cccc}
\hline Set size & $\begin{array}{c}\text { Bulb } \\
\text { diameter } \\
(\mathbf{m m})\end{array}$ & $\begin{array}{c}\text { Bulb weight } \\
(\mathbf{g})\end{array}$ & $\begin{array}{c}\text { Total yield } \\
\left(\mathbf{g ~ m}^{-2}\right)\end{array}$ \\
\hline S1 & $42.12^{\mathrm{b}}$ & $48.18^{\mathrm{c}}$ & $2141.6^{\mathrm{c}}$ \\
S2 & $55.53^{\mathrm{a}}$ & $84.46^{\mathrm{b}}$ & $3753.9^{\mathrm{b}}$ \\
S3 & $58.71^{\mathrm{a}}$ & $109.43^{\mathrm{a}}$ & $4863.5^{\mathrm{a}}$ \\
\hline
\end{tabular}

Means within the same column followed by the same letter(s) are not significantly different $(\mathrm{p} \leq 0.05)$ from each other, according to Duncan`s Multiple Range Test (DRMT). Set size: $\mathrm{S} 1=$ small $(3 \pm 1$ $\mathrm{g} / \mathrm{set}), \mathrm{S} 2=$ medium $(6 \pm 1 \mathrm{~g} / \mathrm{set}), \mathrm{S} 3=$ large $(10 \pm 1 \mathrm{~g} / \mathrm{set})$.

Addai (2014) reported that, in order to get the higher yield in 'Bawku red' or 'White onion' farmers have to grow the large set size (45-60 $\mathrm{mm}$ in diameter). Larger bulb size is also suggested for the onion seed production, $776.67 \mathrm{~kg} \mathrm{ha}^{-1}$ which is the highest onion seed yield was obtained from the largest bulb $15 \pm 2$ g/set by (Asaduzzaman et al., 2012). Significant effect of set size recorded among all three set sizes. The larger bulb set gave the highest total yield, where the largest total yield was from the biggest set size $10 \pm 1 \mathrm{~g} / \mathrm{set}$ at $4863.5 \mathrm{~g}$ followed by medium set size $6 \pm 1 \mathrm{~g} / \mathrm{set}$ at $3753.9 \mathrm{~g}$ then small set size $3 \pm 1 \mathrm{~g}$ at $2141.6 \mathrm{~g} / \mathrm{set}$. Mondal and Alam (2003) mentioned that a larger bulb size contains more food and substances for the plant to use during its vegetative growth. Similar result was recorded by Ud-Deen (2008) who provided that the greatest bulb yields $17.52 \mathrm{t} \mathrm{ha}^{-1}$ was obtained in the largest mother bulb planting size $20 \mathrm{~g} / \mathrm{set}$.

\section{Effect of MLE on bulb diameter, weight, and total} yield $\left(\mathrm{g} \mathrm{m}^{-2}\right)$ of onions

The results from Table 3 show a significant increase in the average bulb diameter, weight and total yield (g $\mathrm{m}^{-2}$ ) of 'Texas Early White' onion cultivar. All of the levels of MLE lead to significant increases in the comparison of the measured parameters to the control. However, with increasing the concentration from $4 \%$ to $6 \%$, the parameters gradually decreased. Similar results recorded in the experiment by El-nour and Ewais, (2017) on pepper seed germination, vegetative growth, yield and quality where the parameters reduced with the increase of MLE concentration from $4 \%$ to $6 \%$. Plants sprayed with 4\% MLE produced the highest bulb diameter $57.55 \mathrm{~mm}$ followed by $6 \%$ and $2 \%$ at 53.12 $\mathrm{mm}$ and $52.33 \mathrm{~mm}$, respectively.

A similar result was recorded in bulb weight sprayed with $4 \%, 6 \%$, and $2 \%$ at $99.74 \mathrm{~g}, 84.49 \mathrm{~g}$ and 82.92 g respectively. Meanwhile, the lowest bulb size was obtained by the control treatment. The highest total bulb yield was in the treatment of $4 \%$ of MLE followed by $6 \%$ and $2 \%$ at $2814.5 \mathrm{~g} \mathrm{~m}^{-2}$ and $2764 \mathrm{~g} \mathrm{~m}^{-2}$, respectively. However, the only significant difference recorded was in the treatment of $4 \%$ of MLE, compared to the control at $3324.5 \mathrm{~g}$. With the increase of MLE concentration from $4 \%$ to $6 \%$, the total yield was gradually decreasing. Similar results obtained in the pepper (Capsicum annuиm L.) vegetation growth, seed germination and yield improvement using $4 \%$ of MLE (El-nour and Ewais, 2017).

Table 3

Effect of MLE concentration on size, weight, and total yield of onion $\left(\mathrm{g} \mathrm{m}^{-2}\right)$

\begin{tabular}{cccc}
\hline $\begin{array}{c}\text { MLE } \\
\text { treatment }\end{array}$ & $\begin{array}{c}\text { Bulb } \\
\text { diameter } \\
(\mathbf{m m})\end{array}$ & $\begin{array}{c}\text { Bulb weight } \\
(\mathbf{g})\end{array}$ & $\begin{array}{c}\text { Total yield } \\
\left(\mathbf{g ~ m}^{-2}\right)\end{array}$ \\
\hline T0 & $45.48^{\mathrm{b}}$ & $55.61^{\mathrm{b}}$ & $1869.35^{\mathrm{b}}$ \\
T1 & $52.33^{\mathrm{a}}$ & $82.92^{\mathrm{a}}$ & $2764^{\mathrm{ab}}$ \\
T2 & $57.55^{\mathrm{a}}$ & $99.74^{\mathrm{a}}$ & $3324.53^{\mathrm{a}}$ \\
T3 & $53.12^{\mathrm{a}}$ & $84.49^{\mathrm{a}}$ & $2814.5^{\mathrm{ab}}$ \\
\hline
\end{tabular}

Means within the same column followed by the same letter(s) are not significantly different $(\mathrm{p} \leq 0.05)$ from each other, according to Duncan`s Multiple Range Test (DRMT)

MLE: Moringa leaf extract

Treatments $=\mathrm{T} 0(0 \%)$ control, $\mathrm{T} 1(2 \%), \mathrm{T} 2(4 \%), \mathrm{T} 3(6 \%)$ of MLE

\section{Interaction effect of MLE and set size on bulb diameter, weight, and total yield of onions}

Data in Table 4 illustrates the statistical differences among all the recorded parameters at $(\mathrm{p} \leq 0.05)$ with the interaction effect of MLE and set size in comparison to the control. The greatest reaction of the set size was in the interaction between the largest set size with the different MLE concentrations. The most influenced parameters recorded in the medium and large set size with the MLE concentration of $4 \%$, while the lowest result was in the smallest set size with control treatment. A significant difference in the bulb weight recorded for the large onion set size sprayed with $4 \%$ of the MLE at $144.08 \mathrm{~g} /$ piece followed by the large set size of $6 \%$ and $2 \%$ of MLE at $122.52 \mathrm{~g} / \mathrm{piece}$ and $103.41 \mathrm{~g} /$ piece respectively. Azooz et al. (2004) have mentioned that spraying with different MLE concentrations leads to improve plant productivity, yield and chemical contents in the fruit.

Similar result was recorded for 4\% MLE and the three different set sizes (small, medium, large), 51.73 g/piece, $103.41 \mathrm{~g} / \mathrm{piece}$ and $144.08 \mathrm{~g} / \mathrm{piece}$, respectively. This result agrees with Mvumi et al. (2013) and Culver (2012) that tomatoes recorded the best yield spraying with MLE 4 times every two weeks interval. The largest bulb size was achieved from the largest set size $(10 \pm 1 \mathrm{~g})$ with $4 \%$ of MLE at $68.90 \mathrm{~mm}$ while the smallest set size recorded from the smallest set size $(3 \pm 1 \mathrm{~g})$ with control $38.40 \mathrm{~mm}$. A significant difference was also recorded for the bulb total yield among the parameters. The highest bulb yields 4802.7 $\mathrm{g} \mathrm{m}^{-2}$ recorded in the interaction of plants sprayed with the $4 \%$ of MLE and larger set size $(10 \pm 1 \mathrm{~g})$ while the lowest total yield $1530.8 \mathrm{~g} \mathrm{~m}^{-2}$ recorded by the control 
with the set size of $(3 \pm 1 \mathrm{~g})$. Except for the control, all the other parameters recorded significant difference between their replications. Finally, the combination of large set size X 4\% MLE recorded the best result for the bulb diameter, weight and the total yield. This result is in conformity with the research study result by
Mondal and Alam (2003) where the highest yield/hectare was in the combination of large bulb $\mathrm{x}$ IAA (Indole-3-acetic acid) (200 ppm), whereas the lowest was in the combination of small bulb $\mathrm{x}$ control (0\% MLE) treatment.

Interaction effect of MLE and set size bulb diameter ( $\mathrm{mm})$, weight $(\mathrm{g})$, and yield $\left(\mathrm{g} \mathrm{m}^{-2}\right)$ of onions

\begin{tabular}{|c|c|c|c|c|}
\hline $\begin{array}{c}\text { Treatments of } \\
\text { Moringa }\end{array}$ & Set sizes & $\begin{array}{l}\text { Diameter } \\
\text { (mm) }\end{array}$ & $\begin{array}{l}\text { Weight } \\
\text { (g/piece) }\end{array}$ & $\begin{array}{l}\text { Bulb yield } \\
\qquad\left(\mathrm{g} \mathrm{m}^{-2}\right)\end{array}$ \\
\hline \multirow{3}{*}{ T0 } & S1 & $38.40^{\mathrm{e}}$ & $45.93^{\mathrm{e}}$ & $1530.8^{\mathrm{e}}$ \\
\hline & S2 & $52.04^{\mathrm{cd}}$ & $61.56^{\mathrm{de}}$ & $2052.2^{\mathrm{de}}$ \\
\hline & S3 & $46.00^{\text {cde }}$ & $59.33^{\mathrm{de}}$ & $1977.7^{\mathrm{de}}$ \\
\hline \multirow{3}{*}{$\mathrm{T} 1$} & S1 & $42.62^{\mathrm{de}}$ & $46.91^{\mathrm{e}}$ & $1597.1^{\mathrm{e}}$ \\
\hline & $\mathrm{S} 2$ & $57.34^{\mathrm{b}}$ & $92.08^{\mathrm{cd}}$ & $3069.3^{\text {cd }}$ \\
\hline & S3 & $57.02^{\mathrm{b}}$ & $103.41^{\mathrm{bc}}$ & $3726^{\mathrm{bc}}$ \\
\hline \multirow{3}{*}{$\mathrm{T} 2$} & S1 & $44.72^{\text {cde }}$ & $51.73^{\mathrm{e}}$ & $1724.4^{\mathrm{e}}$ \\
\hline & S2 & $59.03^{\mathrm{ab}}$ & $103.41^{\mathrm{bc}}$ & $3447^{\mathrm{bc}}$ \\
\hline & S3 & $68.90^{c}$ & $144.08^{\mathrm{a}}$ & $4802.7^{\mathrm{a}}$ \\
\hline \multirow{3}{*}{$\mathrm{T} 3$} & S1 & $42.74^{\mathrm{de}}$ & $50.16^{\mathrm{e}}$ & $1672.2^{\mathrm{e}}$ \\
\hline & S2 & $53.71^{\mathrm{bc}}$ & $80.79^{\text {cde }}$ & $2697.7^{\text {cde }}$ \\
\hline & S3 & $62.92^{\mathrm{ab}}$ & $122.52^{\mathrm{ab}}$ & $4081.4^{\mathrm{ab}}$ \\
\hline
\end{tabular}

Means within the same column followed by the same letter(s) are not significantly different $(\mathrm{p} \leq 0.05)$ from each other, according to Duncan`s Multiple Range Test (DRMT)

Set sizes: $\mathrm{S} 1=$ Small $(3 \pm 1 \mathrm{~g} / \mathrm{set}), \mathrm{S} 2=$ Medium $(6 \pm 1 \mathrm{~g} / \mathrm{set}), \mathrm{S} 3=$ Large $(10 \pm 1 \mathrm{~g} / \mathrm{set})$

Treatment of Moringa extract: T0: control; T1: 2\% MLE; T2: 4\% MLE and T3: 6\% MLE.

\section{CONCLUSIONS}

Interaction of foliar spray of Moringa leaf extract and large set size resulted in the best potential to improve the bulb diameter, weight and total yield of onions, because Moringa leaf contains many different mineral nutrients and some growth hormones. Larger set size also contains more nutrients for the plant to use during its growing period and development. Based on our result, Moringa leaves extract is a useful natural extract to be used as a foliar spray to increase onion yield. Therefore, large set size $(10 \pm 1 \mathrm{~g} / \mathrm{set})$ spray with $4 \%$ of MLE is recommended for the 'Texas Early White' onion cultivar because the yield was improved by $44 \%$ in the use of MLE compare to the control.

\section{REFERENCES}

Abdissa, Y.-Tekalign, T.-Pant, L.M. (2011): Growth, bulb yield and quality of onion (Allium cepa L.) as influenced by nitrogen and phosphorus fertilization on vertisol I. growth attributes, biomass production and bulb yield. African J. Agric. Res. 6, 3252-3258. https://doi.org/10.5897/AJAR10.1024

Addai, I. (2014): Effects of Cultivar and Bulb Size on Growth and Bulb Yield of Onion (Allium cepa L.) in the Northern Region of Ghana. Br. J. Appl. Sci. Technol. 4, 2090-2099. https://doi.org/10.9734/bjast/2014/8458

Antwi-Boasiako, C.-Enninful, R. (2011): Effects of growth medium, a hormone, and stem-cutting maturity and length on sprouting in Moringa oleifera Lam. J. Hortic. Sci. Biotechnol. 86, 619-625. https://doi.org/10.1080/14620316.2011.11512813

Asaduzzaman, M.-Hasan, Md.-Mainul Hasan, Md.-Mahmudul Moniruzzaman, M.-Kabir Howlander, M.H. (2012): Effect of bulb size and plant spacing on seed production of onion (Allium cepa L.). Bangladesh J. Agric. Res. 37, 405-414. https://doi.org/10.3329/bjar.v37i3.12084
Azooz, M.M.-Shaddad, M.A.-Abdel-Latef, A. (2004): The accumulation and compartment-ation of proline in relation to salt tolerance of three sorghum cultivars. Ind. J. Plant Physiol 9, 18.

Culver, M.-Fanuel, T.-Chiteka, A.Z. (2012): Effect of Moringa Extract on Growth and Yield of Tomato. Greener J. Agric. Sci. 2, 207-211.

El-nour, H.A.-Ewais, A. (2017): Effect of Moringa oleifera Leaf Extract (MLE) on Pepper Seed Germination, Seedlings Improvement, Growth, Fruit Yield and its Quality. Middle East J. Agric. Res. 6, 448-463.

El-saady, W.A.-Omar, G.F. (2017): Impact of Some Bio-Stimulants on Growth, Yield and Quality of Head Lettuce (cv, Big bell). Int. J. Environ. Stud. 6, 178-187.

FAO (2017): Onion production [WWW Document]. URL http://www.fao.org/faostat/en/\#data/QC (accessed 1.16.20).

Fuglie, L. (2000): The Miracle Tree: Moringa oleifera: Natural Nutrition for the Tropics. The multiple Attributes of Moringa. p. 172. 
Fuglie, L. (1999): The Miracle Tree: Moringa oleifera: Natural Nutrition for the Tropics. Church World Service, Dakar. 68 pp.; revised in 2001 and published as The Miracle Tree: The Multiple Attributes of Moringa, Darka. ed. Church World Service.

Fuglie, L.J. (2009): ECHO Development Notes 1-8.

Griffiths, G.-Trueman, L.-Crowther, T.-Thomas, B.-Smith, B (2002): Onions - A global benefit to health. Phyther. Res. 16, 603-615. https://doi.org/10.1002/ptr.1222

Hanelt, P. (1990): Taxonomy, evolution and history, In 'Onions and allied crops. Vol I. Botany, physiology and genetics'.(Eds HD Rabinowitch, JL Brewster).

Hassan, M.-Ayoub, A. (1978): Effects of N, P and K on Yield of Onion in the Sudan Gezira. Exp. Agric. 14, 29-32. https://doi.org/doi:10.1017/S0014479700008309

Hegazi, A.-Hasan, S.-El-Said, N. (2016): Response of Garlic Plants To Foliar Application of Moringa Leaves Extract, Glutamine and Cysteine. J. Plant Prod. 7, 1-6. https://doi.org/10.21608/jpp.2016.43438

Islam, M.K.-Awal, M.A.-Ahmed, S.U.-Baten, M.A. (1999): Effect of Different Set Sizes, Spacings and Nitrogen Levels on the Growth and Bulb Yield of Onion. Pakistan J. Biol. Sci. 2, 1143 1146. https://doi.org/10.3923/pjbs.1999.1143.1146

Matimati, I.-Murungu, S.F.-Handiseni, M.-Dube, Z.P. (2006) Effect of Set Size and Cultivar on Marketable Yield of Onion (Allium cepa). J. New Seeds 8, 61-70. https://doi.org/10.1300/J153v08n01

Matthew, A. (2016): Moringa leaf extract on the growth and yield of Pepper (Capsicum annuum L.). ARPN J. Agric. Biol. Sci. 11, 107-109.

Mohammed, R.-Olorukooba, M.-Akinyaju, J.-Kambai, E. (2013): Evaluation of Different Concentrations And Frequency of Foliar Application of. Agrosearch 13, 196-205. https://doi.org/10.4314/agrosh.v13i3.3

Mondal, M.-Alam, M. (2003): Effects of set size and growth regulators on growth and yield of onion. J. Bangladesh Agric. Univ. 1, 7-12.
Mondal, M.F.-Brewster, J.L.-Morris, G.E.L.-BUTLER, H.A. (1986): Bulb Development in Onion (Allium cepa L.) I. Effects of Plant Density and Sowing Date in Field Conditions. Ann. Bot. 58, 187-195. https://doi.org/10.1093/oxfordjournals.aob.a087197

Mvumi, C.-Tagwira, F.-Chiteka, A. (2013): Effect of Moringa Extract on Growth and Yield of Maize and Common Beans. Greener J. Agric. Sci. 3, 055-062. https://doi.org/10.15580/gjas.2013.1.111512264

Prosecus, P. (2006): Biosynthesis-plant hormones and growth regulators: Chemistry and Biology. Biosynth Ag. Co., Switzerland.

Rabinowitch, H.D. (1979): Doubling of onion bulbs as affected by size and planting date of sets. Ann. Appl. Biol. 93, 63-66.

Rady, M.M.-Mohamed, G.F. (2015): Modulation of salt stress effects on the growth, physio-chemical attributes and yields of Phaseolus vulgaris $\mathrm{L}$. plants by the combined application of salicylic acid and Moringa oleifera leaf extract. Sci. Hortic. (Amsterdam). 193, 105-113. https://doi.org/10.1016/j.scienta.2015.07.003

Ruiter, J.M. de (1986): The effects of temperature and photoperiod on onion bulb growth and development. Proc. Agron. Soc. NZ $16,93-100$

Sreelatha, S.-Padma, P.R. (2009): Antioxidant Activity and Total Phenolic Content of Moringa oleifera Leaves in Two Stages of Maturity 303-311. https://doi.org/10.1007/s11130-009-0141-0

Taiz, L.-Zeiger, E. (2010): Plant Physiology. Sinauer, Sunderland, MA.

Ud-Deen, M.M. (2008): Effect of mother bulb size and planting time on growth, bulb and seed yield of onion. Bangladesh J. Agric. Res. 33, 531-537.

Yamaguchi, M.-Paulson, K.N.-Kinsella, M.N.-Bernhard, R.A. (1975): Effects of soil temperature on growth and quality of onion bulbs (Allium cepa L.) used for dehydration. No Res. 
